\title{
Die opstanding van Jesus Christus as historiese gebeure
}

\author{
Ernest van Eck (Oos-Moot, Pretoria)* \\ Navorsingsassosiaat: Departement Nuwe-Testamentiese Wetenskap \\ Universiteit van Pretoria
}

\begin{abstract}
The resurrection as historical event

In this article the understanding of the resurrection of Jesus by William Lane Craig, Gerd Lüdemann and John Dominic Crossan are used as starting point to discuss two issues with regard to the study of the resurrection of Jesus: the relationship between presuppositions and results in a theological enterprise, and the nature of the texts in the New Testament as either theology or as history. Attention is also given to the notion history as such. Finally, a thesis of the resurrection of Jesus as being historically probable, is postulated.
\end{abstract}

\section{INLEIDENDE OPMERKINGS}

In 'n vorige artikel (kyk Van Eck 2004:533-552) is 'n kort beskrywing aangebied van die verwagtinge wat geheers het ten opsigte van lewe na die dood in die Joodse en Grieks-Romeinse wêrelde, waarna aandag gegee is aan die "saak" wat die Nuwe Testament ten opsigte van die opstanding van Jesus kommunikeer. Vervolgens word aandag gegee aan die standpunte van drie prominente deelnemers aan die huidige debat oor die opstanding, te wete Gerd Lüdemann, John Dominic Crossan en William Lane Craig. Genoemde Nuwe-Testamentici se standpunte word gebruik as vertrekpunt om twee sake wat van belang is in die ondersoek na die opstanding van Jesus, aan die orde te stel: die verhouding tussen vooronderstellings en resultate (in die ondersoek na die opstanding van Jesus Christus) en die aard van die tekste van die Nuwe Testament as geskiedenis en teologie. Vervolgens word aandag gegee aan die begrip "geskiedenis", waarna 'n eie verstaan van die opstanding as 'n histories-waarskynlike gebeure aangebied word.

\footnotetext{
* Dr Ernest van Eck (MA, DD) is as navorsingsassosiaat betrokke by prof dr Andries G van Aarde se navorsingsprojek "Bybelse Teologie en Hermeneutiek", Departement NuweTestamentiese Wetenskap, Fakulteit Teologie, Universiteit van Pretoria.
} 


\title{
2. DIE OPSTANDING VAN JESUS CHRISTUS: ENKELE FASETTE VAN DIE DEBAT IN DIE VERLEDE EN HEDE
}

Die Christelike kerk, op grond van die getuienis van die Nuwe Testament, bely dat Jesus Christus deur God uit die dood opgewek het. O'Collins (1997:5-6) druk hierdie oortuiging soos volg uit:

\begin{abstract}
After his crucifixion and burial, through a special divine action that set the ultimate seal of approval on his life and work, Jesus was personally delivered from the state of death; with his earthly body transformed and taken up into a glorified existence, he initiated the end of all things for all human beings and their world. The postresurrection appearances ... showed that Jesus' resurrection was not primarily "for him" (pro se) but also secondarily "for us" (pro nobis). ${ }^{1}$
\end{abstract}

(O'Collins 1997:5-6)

Van baie vroeg af egter is die oortuiging (belydenis) dat Jesus Christus uit die dood opgewek is, met teenkanting begroet. In die woorde van Weltin (in Riley 1995:59): "The Jewish idea of resurrection of the whole person was so novel that it boggled the mind of pagan and gentile Christian alike. Many found it quaint, utterly ridiculous, or downright repulsive." Celsus ${ }^{2}$, byvoorbeeld, het geoordeel dat die moontlikheid van 'n liggaamlike opstanding absurd is. Die oorsprong van so 'n oortuiging kon daarom net, volgens hom, geleë wees in histerie, drome, leuens of hallusinasies (Celsus, in Origines, Contra Celsum 11.55; kyk Van Tilborg \& Chatelion Counet 2000:205). Polikarpus, Justinus die Martelaar ${ }^{3}$, Irenaeus en Tertullianus het, op hulle beurt weer, die liggaamlike opstanding van Jesus Christus met felheid teen alle opponente van die liggaamlik opstanding (bv Origines en Marsion) verdedig.

Tans word hierdie debat weer in felheid gevoer. In die afgelope aantal jare het soveel publikasies in hierdie verband die lig gesien, dat dit feitlik onmoontlik is om enigsins te probeer om 'n bevatlike oorsig oor die standpunte van die eksponente van die huidige debat neer te pen. In wat volg, is daarom bewustelike seleksie toegepas. Aandag word gegee aan die standpunte van Lüdemann, Crossan en Craig, asook dié van NuweTestamentici wat óf genoemde drie geleerdes ondersteun, óf van hulle verskil. Die oordeel word gevel dat hierdie seleksie nie 'n reduksie van die huidige debat tot gevolg sal hê nie, en wel die sake op die tafel sal plaas wat as verteenwoordigend van die huidige debat gesien kan word. 


\subsection{Gerd Lüdemann}

Lüdemann se historiese ondersoek van die tekste van die Nuwe Testament wat handel oor die dood, begrafnis en opstanding van Jesus Christus bring hom tot die volgende konklusie:

[W]e can no longer understand the resurrection of Jesus in a literal sense ... for historically speaking we do not know the slightest thing about the tomb (was it empty? was it an individual tomb at all?) and about the fate of Jesus' corpse: did it decay?

(Lüdemann 1994:180)

Hoe kom Lüdemann tot hierdie gevolgtrekking? Drie sake kan hier gemeld word:

- $\quad$ Die vertellinge oor die dood en opstanding van Jesus is antieke tekste wat nie deur ooggetuies neergepen is nie. Nie een van die vier Evangeliste was ooggetuies van Jesus se lewe, dood en opstanding nie. Ook Paulus, wat aanspraak maak dat hy die opgestane Heer gesien het, het Jesus nie geken nie (Lüdemann 2000a:41);

- $\quad$ niemand weet wat met Jesus se liggaam gebeur het na sy dood nie. Jesus is nie in 'n begraafplaas vir tereggestelde persone begrawe nie ( $\mathrm{Hy}$ is nie deur die Jode tereggestel nie) en die tradisie dat Josef van Arimatea Jesus begrawe het is uiters tendensieus. ${ }^{4}$ Verder berig Handelinge 13 dat 'n aantal Jode Jesus begrawe het. ${ }^{5}$ Hierdie twee tradisies weerspreek mekaar duidelik (Lüdemann 1994:44-45; 2000a: 43); en

- $\quad$ in die oudste tradisie wat aan ons bekend is oor die begrafnis van Jesus (1 Kor 15:3-5) dra Paulus geen kennis van die leë graf nie (Lüdemann 1994:45-47; 2000a:44).

Waar moet ons dan gaan soek na die oorsprong van die geloof in die opstanding van Jesus Christus? In die woorde van Lüdemann:

At the heart of the Christian religion lies a vision described in Greek by Paul as ophthe - "he was seen." And Paul himself, who claims to have witnessed an appearance, asserted repeatedly, "I have seen the Lord." So Paul is the main source of the thesis that a vision is the origin of the belief in the resurrection. 
Met 1 Korintiërs 15:3-8 as "basisteks" verduidelik Lüdemann (1994:37-96) bogenoemde vertrekpunt soos volg: 1 Korintiërs 15:3-8 bestaan uit vier tradisies, te wete 1) Jesus het gesterf, 2) Hy is begrawe, 3) Hy het op die derde dag opgestaan, en 4) as bewys dat Hy lewe, het Hy eers aan Petrus (en die twaalf) verskyn, daarna aan vyfhonderd broers tegelyk, toe aan Jakobus, en laastens aan Paulus self.

Hoe moet hierdie verskynings van Jesus verstaan word? Deur gebruik te maak van die resultate van hedendaagse navorsing van die dieptepsigologie oor rou, oordeel Lüdemann (1994:96-98) dat Petrus (as gevolg van sy verloëning van Jesus) ervaringe van skuld en verlies beleef het. Nie lank na Jesus se dood het Petrus egter weer Jesus se woorde van vergiffenis "gehoor", en so het hy Jesus "gesien": "Cephas saw Jesus alive in a vision which also had auditory features. He experienced the word of Jesus as something living, as an encounter with the whole Jesus himself, in an image" (Lüdemann 1994:96, 174). Hierdie gebeure het 'n bepaalde kettingreaksie tot gevolg gehad: die nuus oor Petrus se "sien" van Jesus het soos 'n veldbrand versprei, en baie vinnig het Jesus ook aan die Twaalf "verskyn", en daarna aan vyfhonderd broers tegelyk.

Wat laasgenoemde verskyning betref, oordeel Lüdemann (1994:102) dat Paulus hier (in 1 Kor 15:6) na die gebeure van Handelinge 2:1-13 verwys. Verstaan vanuit die perspektief van massa-psigologie, was die verskyning van Jesus aan die vyfhonderd ' $n$ historiese gebeurtenis in die sin van massaekstase, met as stimulus sowel Petrus (en die Twaalf) se "sien" van Jesus, as die prediking oor Jesus wat intussen plaasgevind het. Heel waarskynlik het Jesus ook, tydens hierdie gebeurtenis aan Jakobus "verskyn" (Lüdemann 1994:109).

Laastens het Jesus aan Paulus self verskyn. Volgens Lüdemann (1994:79-84) moet Paulus se "sien" van Jesus so verstaan word: gesien vanuit die diepte-psigologie (en Jung se verstaan van die argetipe ${ }^{6}$ ) het Paulus se vervolging van die vroeë Christene gekulmineer in 'n opbouende kompleks van skuld. Gesien vanuit die teorie van Jung, het Paulus egter onbewustelik aanklank gevind by die prediking van die Christene (met inhoud die verkondiging dat 'n Messias gekruisig is vir ander, die universele tendens van die evangelie asook die evangelie as 'n evangelie van liefde). Paulus het dus in wese met 'n onbewuste Christuskompleks gesit, 'n kompleks wat deurbreek as hy Jesus op pad na Damaskus "sien". Wat Paulus dus onbewustelik begeer het, het nou gebeur. ${ }^{7}$

Die na-opstandingvertellings is dus, volgens Lüdemann, histories in dié opsig dat dit verstaan kan word as subjektief-psigologiese gesigte/visioene van Jesus wat werklik plaasgevind het. 


\subsection{John Dominic Crossan}

Crossan (1994:123-158; 1995:160-188) se siening wat betref die (dood en) begrafnis van Jesus, berus op drie vooronderstellings: 'n bepaalde stratifikasie van tekste, sy verstaan van die wyse waarop kruisiging in die Romeine wêreld plaasgevind het, en sekere argeologiese fondse. Wat eersgenoemde betref, kortliks die volgende: die vroegste dokument wat ons het wat handel oor die kruisiging, begrafnis en opstanding van Jesus is die "Kruisevangelie" (Cross Gospel), wat, op sy beurt weer, deel uitmaak van die Evangelie van Petrus. Die skrywer van die Markusevangelie het as bron vir sy weergawe van die kruisiging en opstanding van Jesus net die Kruisevangelie tot sy beskikking gehad, en dit verder uitgebrei deur ' $n$ interpretasie van sekere Ou-Testamentiese gedeeltes (wat Crossan tipeer as historized prophecy). Die Markusevangelie (soos opgeneem in die kanon) was egter nie die oorspronklike vorm van Markus nie. Op grond van die navorsing van Morton Smith is die kanonieke Markus gebaseer op die "Geheime Evangelie van Markus", wat geëindig het by Markus 15:39 (die belydenis van die Romeinse offisier dat Jesus waarlik die Seun van God was). Markus 15:4016:8 is deur Markus bygevoeg. Die ander evangelies het dan van Markus en die Kruisevangelie gebruik gemaak (kyk inter alia Crossan 1985, vir 'n kort opsomming van Crossan se stratifikasie van hierdie tekste, kyk ook Craig 1997:250-252).

Wat betref die praktyk van kruisiging in die Romeine kultuur, kortliks die volgende: in die antieke Romeine wêreld was die lot van misdadigers wat gekruisig was die vernedering van geen begrafnis nie: "the final penalty was to lie unburied as food for carrion birds and beasts ... There would be no place where the dead one could be mourned, visited, or remembered" (Crossan 1995:160-161; kyk ook Crossan 1994:126-127). Op grond van die Evangelie van Petrus 5:15-6:22 (die vroegste stratum in die Evangelie van Petrus, te wete die Kruisevangelie), asook die bepaling in Deuteronomium 21:22-23, oordeel Crossan (1995:170) dat die Romeine Jesus se liggaam van die kruis afgehaal het (en heel waarskynlik ook begrawe het): "those who crucified Jesus would have buried him out of obedience to Deuteronomy 21:22-23. [This is not] based on any knowledge of what actually happened but is rather a hope for what surely must have happened" (Crossan 1995:171). Of, soos Crossan (1994:158) dit elders stel: "With regard to the body of Jesus, by Easter Sunday morning, those who cared did not know where it was, and those who knew did not care. Why should even the soldiers themselves remember the death and disposal of a nobody?" Jesus se liggaam is dus heel waarskynlik in 'n vlak graf begrawe, en het heel waarskynlik die prooi geword van roofvoëls en wilde honde (Crossan 1994:160). ${ }^{8}$ 
Volgens Crossan (1994:124-127; 1995:167-168) word bogenoemde moontlikheid ondersteun deur die feit dat tot dusver nog net een persoon wat gekruisig is, se skelet deur argeoloë gevind is, en wel in 1968 te Giv'at haMivtar, net noord van Jerusalem in 'n graf wat dateer uit die eerste eeu na Christus. Hierdie argeologies fonds, aldus Crossan (1995:168), bevestig bogenoemde verstaan van die (moontlike) begrafnis van Jesus.

Wat betref die opstanding van Jesus (of dan, die naopstandingverskynings van Jesus) oordeel Crossan (1994:160-161) dat dit op ten minste drie moontlike wyses verstaan kan word: as opstanding, as verskynings van Jesus ("apparitions") of as die kontinue ervaring van bemagtiging deur Jesus. ${ }^{9}$ Crossan (1995:203) kies vir die laaste moontlikheid, en oordeel verder dat die vertellinge oor die verskynings van Jesus na sy "opstanding" "profoundly political implications" gehad het: "They are not primarily interested in trance, ecstasy, apparition, or revelation but in authority, power, leadership, and priority" (Crossan 1995:203).

Crossan grond hierdie verstaan van die na-opstandingverskynings van Jesus in die volgende lees van Lukas-Handelinge: eers verskyn Jesus in Lukas 24:13-36 aan twee persone (op pad na Emmaus) wat deel was van die volgelinge van Jesus voor sy dood. Wanneer Jesus die brood breek, ervaar hulle die teenwoordigheid van Jesus en word bemagtig om die koninkryk te gaan lewe soos Jesus dit voor sy dood met woord en daad aan hulle bekend gemaak het. Hulle haas hulle dan ook terug na die Elf om hierdie bemagtiging en ervaring met hulle te deel. Wanneer Lukas egter in Handelinge 1:1-14 hierdie gebeure "oorvertel", is net die apostels teenwoordig. 'n Verdere ontwikkeling vind plaas in Lukas 24:12 en Lukas 24:33-35, waar Petrus selfs getuienis van die leë graf word, en die twee van Emmaus, wanneer hulle terugkeer, eers vertel dat Jesus aan Simon verskyn het, voordat hulle hulle eie ervaring met die Elf deel. 'n Bepaalde beweging kan dus hier aangetoon word: "general community to leadership group and from leadership group to this or that specific leader" (Crossan 1995:205).

Hierdie verband tussen verskyning en outoriteit, oordeel Crossan (1995:203-205), is ook die sleutel vir die verstaan van 1 Korintiërs 15:3-11. In hierdie gedeelte word Petrus en die Twaalf duidelik geposisioneer teenoor Jakobus en die apostels. Hoekom die onderskeid wat hier gemaak word tussen die Twaalf en die apostels? Sodat Paulus ook as apostel gereken kan word. ${ }^{10}$ So verstaan, is hierdie vertellinge in wese tekste wat handel oor outoriteit, mag en leierskap. 


\subsection{William Lane Craig}

Craig se standpunt ten opsigte van die opstanding van Jesus kan soos volg saamgevat word:

Any adequate historical hypothesis about the resurrection must explain four established facts: Jesus' burial, the discovery of his empty tomb, his postmortem appearances and the origin of the disciples" belief in his resurrection. The best explanation of these facts is that God raised Jesus from the dead.

(Craig 2000a:32)

Craig (2000a:32-34) begrond bogenoemde vier "established facts" soos volg: Na sy kruisiging is Jesus deur Josef van Arimatea begrawe. Hierdie feit is belangrik, want dit beteken dat die plek waar Jesus begrawe is, bekend was. Dit beteken ook dat die dissipels kon verkondig dat Jesus opgestaan het, aangesien 'n leë graf aanduibaar was. Craig vind die volgende NuweTestamentiese getuienis as begronding van hierdie oortuiging: Paulus verwys na Jesus se begrafnis (1 Korintiërs 15:3-5); die vertelling oor die begrafnis van Jesus vorm deel van die vroegste tradisies wat deur Markus gebruik is; Matteus en Johannes se vertellings oor die begrafnis van Jesus berus op verdere onafhanklike bronne, en Handelinge 2:29 en 13:37 verwys ook na Jesus se begrafnis; Josef van Arimatea, wat Jesus begrawe het, was deel van die Joodse Raad wat Jesus veroordeel het, en is dus beswaarlik 'n skepping van die vroeë kerk; die vertelling oor die begrafnis van Jesus toon geen spore van legendariese ontwikkeling nie; en die Nuwe Testament bevat geen ander (konflikterende) vertelling oor die begrafnis van Jesus nie.

Op die Sondag na Jesus se kruisiging is Jesus se graf leeg gevind deur 'n aantal vroue wat volgelinge van Jesus was. Die volgende argumente, aldus Craig (2000a:33) bevestig die tradisie van die leë graf: soos in die geval van die begrafnis van Jesus, maak die vertelling oor die leë graf deel uit van die vroegste tradisies wat deur Markus gebruik is; 1 Korintiërs 15:3-5 impliseer dat die graf leeg was; ook die vertelling oor die leë graf toon geen spore van legendariese ontwikkeling nie; die feit dat die getuienis van vroue in die eerste-eeuse Mediterreense wêreld as van geen waarde gereken is nie, en tog in die vroegste tekste vermeld word, bevestig die historisiteit daarvan; en die vroeg-Joodse aantyging dat Jesus se liggaam uit die graf gesteel is (Matt 28:11-15) impliseer dat die graf leeg was.

Jesus het na sy opstanding by verskeie geleenthede aan verskillende individue en groepe mense (onder verskillende omstandighede) verskyn. Die volgende twee sake kan, volgens Craig (2000a:33-34), as begronding van die 
historisiteit van die verskynings van Jesus dien: die lys van ooggetuies van Jesus se verskynings soos deur Paulus in 1 Korintiërs 15 gelys (Petrus, die Twaalf, die vyfhonderd broers en Jakobus) waarborg dat hierdie verskynings wel plaasgevind het; en die afsonderlike en verskillende vertellings oor die verskynings van Jesus in die Evangelies verskaf onafhanklike getuienis oor die verskynings van Jesus.

Die dissipels van Jesus het geglo dat Hy uit die dood opgewek is, terwyl hulle feitlik geen rede gehad het om dit te glo nie. Volgens Craig (2000a:34) dien die volgende redes as begronding hiervan: Jesus, hulle leier was dood, en die Jode het geen verwagting gehad in 'n Messias wat sou sterf - en nog meer - sou opstaan nie; volgens die Joodse wet is Jesus, omdat Hy gekruisig is, beskou as 'n misdadiger en het dus onder die oordeel van God verkeer; en Joodse verwagtinge oor lewe na die dood het alleen voorsiening gemaak vir die moontlikheid van 'n eskatologiese algemene opstanding, beslis nie dat iemand voor hierdie eskatologiese gebeure uit die graf sou opstaan nie.

Volgens Craig (2000a:36-37) kan bogenoemde feite net op een wyse verklaar word: God het Jesus uit die dood opgewek. ${ }^{11}$

\subsection{Opsomming}

Bogenoemde standpunte van Craig, Lüdemann en Crossan bied drie moontlikhede van die verstaan van Jesus se opstanding en naopstandingverskynings: Jesus se opstanding en na-opstandingverskynings is 'n historiese feit (Craig), dit is histories in dié opsig dat dit verstaan kan word as subjektief-psigologiese gesigte/visioene van Jesus wat werklik plaasgevind het (Lüdemann), of dit is nie-histories in dié opsig dat die vertellinge oor Jesus se opstanding en na-opstandingverskynings "gemeenteteologie" is wat handel oor mag, gesag en leierskap (Crossan). Met ander woorde: dit het werklik gebeur (Craig), dit het nie gebeur nie maar wel in terme van subjektiewe psigologiese ervarings (Lüdemann), en dit het nie gebeur nie (Crossan).

'n Evaluering van alle fasette van hierdie drie standpunte, die inhoud van die debat oor die opstanding van Jesus tussen hierdie drie geleerdes (kyk o a Craig 2000b, 2000c, 2000d, 2000e; Lüdemann 2000b, 2000c, 2000d, 2000e), asook die inhoud van ander (direkte) deelnemers aan hierdie debat in literêre vorm beskikbaar (kyk o a Eddy 1997, Davis 2000; Goulder 2000; Gundry 2000; Hoover 2000), is onmoontlik. Daarom sal daar, in wat volg, op twee aspekte van die debat gekonsentreer word: die rol wat bepaalde vooronderstellings en keuses vir metodologie speel in terme van spesifieke resultate, en die vraag na die verhouding tussen geskiedenis en teologie. ${ }^{12}$ 


\subsection{Die verband tussen vooronderstellings en resultate: Historiese navorsing en teologie as perspektiwistiese ondernemings}

Soos bo aangetoon, gaan Craig (2000a, 2000d, 2000e) van die vooronderstelling uit dat 'n histories-kritiese lees van die tekste in die Nuwe Testament noodsaaklik is in 'n moontlike poging om die gebeure rondom die dood en opstanding van Jesus te konstrueer. Volgens hom is Markus se weergawe van die leë graf, gelees saam met Matteus en Johannes (as onafhanklike bronne), asook Handelinge 2:29 en 13:37 en 1 Korintiërs 15:3-8, voldoende getuienis om die historisiteit van Jesus se opstanding te aanvaar. Genoemde tekste konstateer vier "feite": Jesus is begrawe, sy graf is leeg gevind, daarna het Jesus aan verskeie persone verskyn, wat gelei het tot die geloof by die eerste volgelinge van Jesus dat Hy opgestaan het en lewe (alhoewel daar baie redes was om dit nie te glo nie). Die enigste manier om hierdie "feite" te verdiskonteer, is om te aanvaar dat God Jesus opgewek het. Verder oordeel hy dat, selfs al sou Lüdemann korrek wees dat nie Josef nie, maar 'n aantal Jode Jesus begrawe het, die betrokkenes tog sou kon gaan wys waar Jesus se graf was om so aan te toon dat Hy nog in die graf was. Volgens Craig (2000a:37) verklaar hierdie verstaan van Jesus se dood en opstanding hoekom die graf leeg gevind is, hoe dit moontlik was dat Jesus na sy dood aan hulle kon verskyn, en hoekom die eerste volgelinge van Jesus geglo het dat Hy lewe. Craig oordeel verder dat sy hipotese in wese net een vooronderstelling nodig het - dat God bestaan, en God daarom so in Jesus kon handel.

Presies op hierdie punt beweeg Lüdemann en Craig se verstaan van Jesus se dood en opstanding uitmekaar. Behalwe dat Lüdemann wesenlik verskil van die historisiteit en onafhanklikheid van die bronne wat Craig lys, is iets soos 'n wonder vir Lüdemann nie moontlik nie: "no modern scientist or historian, outside of some theological circles, imagines that God is intervening" (Lüdemann 2000b:54). Hierdie uitspraak van Lüdemann stel duidelik watter wêreldbeeld hy ondersteun, te wete, dié van die naturalisme. Volgens 'n naturalistiese verstaan van die wêreld bestaan net die sigbare, as ongeskep, uniform en patroonmatig. Geen moontlikheid van onnatuurlike gebeure is moontlik nie (kyk Davis 2000:73).

Die epistemologiese uitgangspunt van 'n naturalistiese wêreldbeeld is dat alle gebeure wetenskaplik-krities ondersoek kan word, en dat 'n logiese verklaring vir enige gebeure aan te bied is. So ook die geval met die vertellings oor die dood en opstanding van Jesus. Volgens Lüdemann (2000b:43) dui 'n (eenvoudige) histories-kritiese ondersoek van hierdie vertellinge daarop dat die gebeure daarin beskryf, nie histories kan wees nie. Dit beteken egter nie dat wat in hierdie tekste beskryf word, nie as 'n 
natuurlike (sigbare) fenomeen verklaar kan word nie. Inteendeel. Visioene/gesigte/hallusinasies - as natuurlike (ondersoekbare) fenomene verklaar wat in hierdie tekste aan die woord is. Hierdie vooronderstellings en metodologie van Lüdemann word raak soos volg deur Tolson (1992:473) uitgedruk: "the generalizing habit inculcated by the scientific world-view ... takes offence at any assertions of 'special' or once-and-for-all experiences and events. This world-view waters down such claims by generalizing them."

Die vraag wat hier gevra kan word, is in hoeverre die ervaringe (visioene) van Petrus en die ander wat volgens Lüdemann Jesus "gesien" het, geobjektiveer kan word. Met ander woorde: is die subjektiewe visioene van Petrus, Maria, die vyfhonderd broers, Jakobus en Paulus meer toeganklik vir wetenskaplike ondersoek as die na-opstandingverskynings van Jesus soos beskryf in die evangelies $?^{13}$ Verder: as ons in ag sou neem dat Jakobus gedurende sy lewe volgens alle beskikbare inligting nie ' $n$ volgeling van Jesus was nie, hoe verklaar Lüdemann - vanuit sy hallusinasiehipotese wat grootliks gebaseer is op berou en verlange - dat Jakobus ook ' $n$ visioen van die opgestane Jesus beleef het (kyk Craig 2000b:49)?

Crossan se vooronderstellings neem hom 'n stap verder wat betref die interpretasie van die opstanding en na-opstandingvertellings soos dit in die Evangelies aangebied word. Deur gebruik te maak van sy bepaalde stratifikasie van tekste (met die onafhanklike Kruisevangelie as die vroegste getuienis), sy verstaan van Romeinse kruisigingprosedures en met gebruikmaking van die resultate van sekere argeologiese fondse, oordeel hy dat Jesus deur die wat Hom gekruisig het, in 'n vlak graf begrawe is. Alles wat hierop volg (bv die tradisie in Markus) is onhistories. Die graf was nie leeg nie, Jesus het nie opgestaan en aan iemand verskyn nie. Daarom kan die naopstandingvertellings van Jesus (in geheel skeppinge van die vroeë kerk) nie anders as sosiologies verstaan word in terme van die strukture van mag, gesag, politiek en bemagtiging nie.

Sou ons egter veronderstel dat die graf wel leeg was, en dat Jesus soos in die Nuwe Testament berig word - wel aan sy volgelinge verskyn het, hoekom sou mense (vanuit 'n Joodse konteks) geoordeel het dat Jesus "opgestaan" het (Crossan 2003:29)? Volgens Crossan word die opstanding van Jesus na die Aufklärung in die meeste gevalle deur óf die "onmoontlikheidsopsie" afgewys, óf deur die "uniekheidopsie" verdedig. In die tyd van Jesus (waarin aanvaar is dat dinge soos maagdelike geboortes en die opstanding van mense moontlik is), was dit egter die sogenaamde "relevansieopsie" wat ter sake was. Die vroeë volgelinge van Jesus sou daarom, wanneer hulle verkondig het dat Jesus opgestaan het en lewe, onmiddellik met die vraag gekonfronteer word: wat het Jesus vir mense 
gedoen? Wat sou hulle antwoord? Dat die opstanding van Jesus nie die opwekking van 'n (amper) dooie persoon is nie, nie bestaan uit "post-mortem apparitions" nie, nie dui op 'n hemelse verhoging nie, maar dat die algemene (eskatologiese) opstanding begin het (Crossan 2003:48).

\subsection{Geskiedenis of teologie?}

Uit bogenoemde is dit duidelik dat verskillende vooronderstellings tot 'n verskil in resultate lei. Wat die verstaan van Jesus se opstanding betref, is dit verder duidelik dat een bepaalde vooronderstelling krities is: word uitgegaan vanuit 'n naturalistiese verstaan van die werklikheid, kan die opstanding van Jesus Christus nie as 'n historiese gebeure verstaan word nie (kyk weer Lüdemann en Crossan hierbo). Volgens 'n naturalistiese (post-Aufklärung) verstaan van die werklikheid bestaan net dit wat tyd-ruimtelik (sintuiglik) waargeneem kan word. Die werklikheid word verder as uniform en patroonmatig (kousaal) verstaan. Geen moontlikheid van onnatuurlike gebeure is moontlik nie (vgl Lüdemann 2000b:54; kyk Davis 2000:73). Borg (1999:130) se verstaan van die opstanding van Jesus is 'n goeie voorbeeld hiervan: alleen as dit wat met Jesus se opstanding en tydens sy na-opstandingverskynings gebeur met 'n videokamera afgeneem sou kon word, kan dit as histories verstaan en aanvaar word. ${ }^{14}$ Omdat dit egter nie kan nie, is Jesus se opstanding nie histories nie. ${ }^{15}$

Strauss $^{16}$, Herrmann ${ }^{17}$, Von Harnack ${ }^{18}$ en Schweitzer ${ }^{19}$ se verstaan van die opstanding is goeie voorbeelde hiervan (kyk Niebuhr 1957:5-15). Jesus se opstanding is ' $n$ wonder, nie deel van die sigbare werklikheid nie, en kan dus alleen metafories verstaan word. Dodd ${ }^{20}$, Brunner $^{21}$, Ritschl $^{22}$, Barth $^{23}$, Bultmann ${ }^{24}$ en $\mathrm{Knox}^{25}$, daarenteen, maak meer van die historisiteit van die Jesusgebeure, maar nogtans beskou hulle nie die opstanding van Jesus as 'n historiese werklikheid nie (kyk Niebuhr 1957:24-71). Oor hierdie geleerdes se ondersoek na die opstanding van Jesus maak Niebuhr (1957:22) die volgende ter saaklike opmerking: dit is duidelik dat beide 'n naturalistiese (histories-kritiese) verstaan van die opstanding as 'n metafisiese verstaan daarvan nie genoeg erns maak met die historisiteit van hierdie gebeure nie.

Laasgenoemde opmerking bring die volgende vraag na vore: Wat is geskiedenis? Volgens Wright (2003:12-15) lei 'n suiwer naturalistiese verstaan van die werklikheid tot 'n verskraling in dit wat as geskiedenis beskou kan word. Die begrip "geskiedenis" het, volgens Wright, ten minste vyf betekenisse: 
- $\quad$ Die begrip geskiedenis kan eerstens na 'n "event" verwys, iets wat gebeur het, al kan dit nie bewys word nie. ' $n$ Voorbeeld hiervan is die uitsterf van die laaste dinosourus.

- $\quad$ Tweedens kan geskiedenis verstaan word as 'n "significant event." Geskiedenis is nie alleen dus iets wat gebeur het nie, maar iets wat gebeur het en 'n bepaalde effek op die verloop van die geskiedenis gehad het.

- $\quad$ Geskiedenis kan ook as 'n "provable event" verstaan word. Dit is nie iets wat alleen wel gebeur het nie, maar 'n gebeure wat wetenskaplik bewys kan word. Omdat dit bewys kan word, is dit histories.

- Vierdens kan geskiedenis verstaan word as "writing-or-speaking-aboutevents-in-the-past". 'n Gebeure is dus histories omdat daaroor geskryf of gepraat is.

- $\quad$ Ten slotte is geskiedenis dit wat die moderne post-Aufklärunghistorikus as geskiedenis aanvaar: alleen dit wat vanuit 'n moderne wêreldbeeld wetenskaplik aanvaarbaar is en as 'n natuurlike gebeure waarneembaar is (of was), kan as histories beskou word. ${ }^{26}$

Niebuhr (1957:165-167) oordeel dat 'n post-Aufklärung verstaan van die werklikheid (en dit wat as histories aanvaar kan word of nie), nie sonder probleme is nie. Vanuit 'n post-Aufklärung epistemologiese ingesteldheid word die werklikheid verstaan as kousaal, met ander woorde, dit word gebind deur sekere algemene natuurwette wat gemeenskaplik in alle gebeure voorkom. Analogieë vir gebeure word gesoek, en as dit gevind kan word, kan 'n bepaalde gebeure as werklik en histories beskou word. So verstaan, word geskiedenis sy eie verklaarder.

Die tekort in hierdie verstaan van die werklikheid (of gebeure) is dat individuele gebeure (dit wat uniek is) nie verklaar kan word nie. Geskiedenis is nie 'n objek as deel van die werklikheid soos ander objekte nie. Gebeure wat deel van die geskiedenis is, is nie altyd universeel nie, dit is soms partikulêr en nie-herhalend. Juis daarom is sommige gebeure individueel vreemd, onomvatbaar, onbeskryfbaar en selfs onverstaanbaar. Ten slotte moet ook onthou word dat geskiedenis (die onmiddellike wat gebeur, gesien en ervaar word) nooit volledig beskryf kan word nie. Geskiedenis (gebeure) word altyd waargeneem, dit word ervaar, en daarom is geskiedenis altyd 'n abstraksie van wat gebeur het (Niebuhr 1975:90, 111).

Wanneer bogenoemde verstaan van wat geskiedenis is, in ag geneem word, oordeel Niebuhr (1957:90-104) dat die opstanding as geskiedenis verstaan en geïnterpreteer kan word. Vyf uitgangspunte is, volgens hom, noodsaaklik vir so 'n ondersoek: 
- $\quad$ Geskiedenis het nie alleen te make met universeel aanvaarbare gebeure nie, maar ook met individuele en nie-herhalende gebeure. Die tradisie oor die opstanding van Jesus Christus in die Nuwe Testament poog nie om in die algemeen oor die moontlikheid van opstanding te handel nie, maar getuig van die opstanding van Jesus Christus as (individuele) gebeure.

- $\quad$ Die opstanding van Jesus Christus kan nie verstaan word buite om die vroeë kerk, en dus die getuienis van die eerste Jesusvolgelinge nie. Dit wat die Nuwe Testament oor die opstanding getuig, is nie feite nie, maar getuienis. Geen geskiedenis (of getuienis) is neutraal nie. Die opstanding is deel van die herinnering van vroeë kerk, en dus, as sodanig, histories van aard. “... [T] he resurrection tradition would not belong to any past at all and so would not be a historical event at all, were it not known by the church" (Niehbuhr 1957:94). Wanneer Jesus van Nasaret van die vroeë kerk se getuienis losgemaak word, is Hy nie meer Jesus Christus nie.

- $\quad$ Die geskiedenis van die vroeë kerk staan in 'n onlosmaaklike verband met die lewe van Jesus Christus. Die verband tussen hierdie twee "geskiedenisse" is die herinnering van die vroeë kerk soos opgeteken in die Nuwe Testament.

- $\quad$ Die getuienis van die eerste volgelinge van Jesus was dat die Jesus wat opgestaan het, Jesus van Nasaret was. Die Jesus wat gekruisig is, is die Jesus wat aan hulle verskyn het. As die opstanding van Jesus gesien word as 'n fabrikasie van die vroeë kerk, moet die herinnering oor Jesus op voor-pase vlak, asook die ontwikkeling van die vroeë geloofsgemeenskap na die opstanding, ook as histories onwaar beskou word.

- $\quad$ Die opstanding van Jesus "is a remembered resurrection". Toegang tot die opstanding van Jesus Christus geskied nie alleen deur die herinnering van die vroeë kerk nie, maar ook deur eie herinnering. Geskiedenis bestaan nooit op sigself nie, alleen wanneer daar 'n (subjektiewe) relasie bestaan tussen subjek (die een wat onthou) en objek (dit wat onthou word) (Niebuhr 1957:97). 


\section{DIE OPSTANDING VAN JESUS CHRISTUS AS GESKIEDENIS}

Uit bogenoemde is twee sake duidelik. Eerstens is eksegese sonder vooronderstellings nie moontlik nie. Meer nog: bewustelike (of onbewustelike) vooronderstellings en keuses vir metodologie bepaal die resultate van enige ondersoek. Epistemologie, metodologie en teleologie staan dus in 'n onlosmaaklike verband tot mekaar. Tweedens: die aard van die teks van die Nuwe Testament (en nie-kanonieke bronne) is geïnterpreteerde geskiedenis. 'n Bepaalde gelaagdheid in hierdie tekste kom na vore, en wel in so 'n mate dat dit dikwels moeilik is om tussen geskiedenis en teologie te onderskei. 'n Saak wat laasgenoemde verder bemoeilik, is die vraag of die skrywers van die Nuwe Testament enigsins in die kategorieë van geskiedenis en teologie gedink het.

Beteken dit dat daar oor die opstanding van Jesus Christus daarom nie eintlik iets gesê kan word nie? Dat ons so diep inval in debatte oor regte of verkeerde vooronderstellings, die stratifikasie van tekste, die keuses van bepaalde metodologieë en beslissings oor wat histories is en wat nie, dat nie veel van dit wat die Nuwe Testament wil kommunikeer, oorbly nie?

Die oordeel word gevel dat daar wel 'n uitweg uit hierdie impasse is, indien daar van die volgende vooronderstellings uitgegaan word:

- $\quad$ Enige poging om die lewe en werk van Jesus van Nasaret te verstaan kan nie van sy opstanding losgemaak word nie. Die digotomie Jesus Christus (die verkondigende Jesus vis-a-vis die verkondigde Christus) los die (historiese) probleem wat Jesus se opstanding betref, nie op nie. Die geloof in Jesus se opstanding is die begin en weefdraad van die vroeë kerk. Die begin van die (vroeë) kerk, asook die ontwikkeling en huidige bestaan daarvan, kan nie verstaan word sonder of losgemaak word van die eerste Jesusvolgelinge se geloof dat Hy opgestaan het nie. Indien die opstanding van Jesus Christus van die tafel gevee word, verdwyn dit wat daarna gekom het, te wete die kerk, in die dryfsand (kyk Niebuhr 1957:v, 1-3).

- $\quad$ Die moderne naturalistiese (post-Aufklärung) verstaan van die werklikheid is nie die enigste moontlikheid om te oordeel of 'n gebeure histories is of nie is nie. Inteendeel, soos hierbo aangetoon, is hierdie werklikheidsbeskouing nie sonder sy probleme nie. Geskiedenis het nie alleen te make met universeel aanvaarbare (verifieerbare) gebeure nie, maar ook met individuele en nie-herhalende gebeure. Die opstanding van Jesus Christus, in die woorde van Wright (2003:12-15), kan nie 
alleen as 'n event beskou word nie, maar ook as significant event. Die opstanding kwalifiseer verder as 'n writing-or-speaking-about-event-inthe-past. Die mening word verder uitgespreek dat die opstanding ook as 'n provable event kwalifiseer. Laasgenoemde uitgangspunt sal hieronder begrond word deur aan te toon word wat histories waarskynlik oor die opstanding gesê kan word.

- $\quad$ "Toegang" tot die opstanding van Jesus bestaan alleen deur die mondelinge tradisie soos dit in die evangelies neerslag gevind het. In hierdie verband word uitgegaan van die standpunt dat, soos die evangelies 'n bepaalde "Jesussaak" op voor-pase vlak kommunikeer ${ }^{27}$, dieselfde geld wat die na-pase vlak betref. Anders gestel: omdat die gebeure rondom Jesus se opstanding en na-opstandingverskynings op na-pase vlak nie aan 'n naturalistiese verstaan van die werklikheid voldoen nie, word dit nie van die tafel gevee nie. Dieselfde gewig word dus toegeken aan die mondelinge tradisie op na-pase vlak as op 'n voor-pase vlak. 'n Bepaalde kontinuïteit word met ander woorde tussen die woorde en dade van Jesus, tradisies wat op grond daarvan ontstaan het, en dit wat uiteindelik skriftelik neerslag gevind het, aanvaar. Hierdie kontinuïteit geld ook vir dit wat na die dood van Jesus gebeur het.

In navolging van Wright (2003:610-613) word verder geoordeel dat die tradisies oor die na-opstandingverskynings van Jesus as redelik vroeg gedateer moet word. Die volgende redes ter begronding van hierdie oortuiging verdien ernstige nadenke:

- Die tradisies oor die na-opstandingverskynings van Jesus in Matteus, Lukas en Johannes toon nie werklik enige ooreenkomste nie (behalwe natuurlik die klem op die identiteit van Jesus). Indien hierdie tradisies skeppinge van die vroeë kerk was, sou geredelik verwag kon word dat hulle in 'n baie groot mate met mekaar sou ooreenkom. Dit is verder, gesien vanuit 'n eerste-eeuse Mediterreense perspektief, ondenkbaar dat, indien hierdie tradisies latere gemeenteteologie is, vroue as getuies aangebied sou word (kyk ook Blomberg 1998:101; Witherington III 1998:141). Interessant is ook dat die tradisies by geen vroeë moontlike antesedent (soos bv Dan 12) aanhaak nie. Wat is die "saak" wat veral die evangelies op die na-pase vlak wil kommunikeer? Jesus is gekruisig en begrawe, die graf was leeg, Hy het opgestaan, en na sy opstanding het Hy aan sy dissipels (en ander) verskyn. ${ }^{28}$ Die 
Jesus wat aan hulle verskyn het, is deur hulle herken as die Jesus wat hulle voor sy dood gevolg het. Daar was by sy dissipels geen twyfel oor die identiteit van die opgestane Here nie (kyk weer Niebuhr 1957:173; Van Eck 2004:533-552).

- Indien die vertellinge oor die opstanding van Jesus in die Nuwe Testament nie wil kommunikeer dat Jesus opgestaan het nie, maar dat sekere persone maar net visioene van (die opgestane) Jesus gehad het (Lüdemann), of dat hulle met hierdie vertellinge eintlik met "politieke" gesagsposisionering besig was (Crossan), moet ons die volgende aanvaar: "[The writers of the New Testament were] either "obtuse communicators", who were unable to express their intended meaning, or "deceptive communicators, who intentionally hid their intended meaning behind the words they used" (Davies 1993:40; kyk ook Craig 1998:42). Die aard van die mondelinge tradisie maak laasgenoemde nie moontlik nie.

In hierdie verband maak Witherington III (1998:135), met verwysing na Lukas 24:19-23 die volgende ter sake opmerking:

Bearing in mind that the report in Luke 24:19-23 is given by the disciples who are leaving Jerusalem and speaking in the past tense about having had hope that Jesus was the one to redeem Israel, we conclude that no mere visions or reports of visions of supernatural beings or reports of empty tombs were going to change these discouraged disciples" mental state. Only an encounter with the risen Lord would do that. There is in this narrative a quality that critiques the male leadership of the early church and at the same time shows that mere visions or claims of visions were not what changed the lives of the disciples.

(Witherington III 1998:135)

- Was Jesus nie maar net 'n Joodse rabbi wat na sy kruisdood binne die raamwerk van die Griekse heldepatroon geïnterpreteer is nie? Wright (2003:64-68) se beskrywing en interpretasie van die verskillende mitologiese vertellings wat in hierdie verband ter sake is, is insiggewend (kyk Van Eck 2004:533-552). Van al die mites wat verwys na 'n terugkeer uit die dood is dit in wese net die Alkestis-mite wat aangebied kan word as bewyslas vir die moontlike geloof in opstanding na die dood onder die Grieke. Alhoewel Alkestis wel, volgens hierdie bekende vertelling, uit die dood terugkeer, sal sy weer sterf (soos 
Lasarus). Volgens hom is een vertelling nie genoeg om te aanvaar dat daar onder die Grieke 'n geloof in opstanding na die dood bestaan het nie. Soos reeds aangetoon (kyk Van Eck 2004:533-552) het Celsus hierdie mites gesien vir wat dit was: mites. Wright (2003:67-68) is verder korrek wanneer hy die volgende opmerkings in hierdie verband maak:

No burial customs invoke Alcestis as patron or model. No prayers are offered that Hercules may do for others what he did to her. No further stories are told which built on or develop the theme. ... Alcestis may have come back (in the ancient legend), but she was the exception .... [These stories] also never became popular reference points as did the great Homeric scenes of Achilles and Odysseus .... One Alcestis ... scarcely makes a tradition. It certainly made no dent in the ruling assumption from Homer to Hadrian and beyond. Life after death, yes; ... actual resurrection, no.

(Wright 2003:67-68)

Dieselfde kan egter nie van die tradisie oor Jesus se opstanding gesê word nie. Na sy opstanding ontstaan daar 'n tradisie, soos bo aangetoon, wat nie anders verstaan kan word as die weefdraad van die vroeë kerk nie. In hierdie verband kan ook gevra word hoe waarskynlik dit sou wees dat die vroeë Christene, in 'n poging om die dood van Jesus te verstaan, van 'n Griekse parallel gebruik sou maak, veral gesien in die lig van Joodse en Romeinse verhoudinge in die tyd van Jesus, asook die (skynbare) rol wat die Romeine in die dood van Jesus gespeel het.

Op grond van bogenoemde vooronderstellings word geoordeel dat die volgende konstruksie gemaak kan word oor dit wat histories waarskynlik met Jesus se opstanding gebeur het:

- In die tyd van Jesus het verskeie populêre profete en messiasse gekom en gegaan (kyk Van Eck 1995:385-387). Hierdie profete en messiasse is feitlik sonder uitsondering deur die Romeinse owerheid (weldadig) doodgemaak. Die betrokke bewegings het daarna opgehou om te bestaan, of het hergroepeer onder die leiding van 'n nuwe persoon. Uit die Evangelies is dit duidelik dat Jesus deur verskeie persone gesien is as maar nog so 'n messias of profeet (vgl Mark 8:2728 en parallelle). Beide hierdie twee sake het egter nie met Jesus se beweging gebeur nie. Kort na sy dood is verkondig dat Hy die ware Messias was, dat Hy opgestaan het en lewe. Indien dit nie die geval was nie, sou niemand die vroeë getuienisse geglo het nie. 
- Wat bogenoemde se historiese waarskynlikheid verhoog, is die feit dat die Jodedom (en die dissipels) alleen geglo het in die algemene opstanding (vgl Joh 11:24). Dat iemand ('n individu) sou opstaan voor hierdie verwagte eskatologiese gebeure, was eenvoudig nie deel van die algemene verwagting onder die Jode nie. Alle verwagtinge in die vroeë kerk het teen so 'n oortuiging getel: die Jode het nie geglo in 'n Messias wat sou sterf en, nog minder, sou opstaan nie. Jesus is verder gekruisig as 'n misdadiger; dus nie iemand wat God se Seun kon wees nie. Tog het die vroeë kerk, sonder enige rede om dit te aanvaar, geglo en verkondig dat Jesus opgestaan het.

- Wat het die vroeë volgelinge van Jesus bedoel as hulle gesê het dat Jesus opgestaan het? Nie dat die algemene opstanding reeds aangebreek het (soos Crossan 2003:48 oordeel) nie, want al die martelare het nie opgestaan nie. Ook nie dat Jesus maar net op een of ander wyse by hulle teenwoordig was nie. Indien laasgenoemde wel die geval was, sou die dissipels nie die verskynings van Jesus as liggaamlik beskryf het nie, maar sou hulle eerder van kategorieë gebruik gemaak het wat op engele of geeste dui. Hoekom, kan verder gevra word, het hierdie verskynings van Jesus op 'n bepaalde punt gestop (vgl 1 Kor 15)? As Jesus net op een of ander wyse teenwoordig was, sou sy "verskynings" mos onbeperk voortgegaan het.

- $\quad$ 'n Verdere belangrike saak is hoe ons die vertellinge oor die vroue as eerste ooggetuies van die leë graf van Jesus, sowel dat Jesus na sy opstanding aan hulle verskyn het, moet interpreteer - veral in die lig van Paulus se duidelike stilswye hieroor in 1 Korintiërs 15:3-8. Indien Crossan en Lüdemann korrek is dat Paulus in 1 Korintiërs 15 soveel as moontlik getuienisse lys om ook sy ervaring van die opgestane Here as waar en feitlik te konstateer, hoekom nie ook na die vroue verwys nie? Die patriargale sisteem van die eerste eeu maak dit hoogs onwaarskynlik dat, indien fiktiewe vertellings oor die leë graf, die opstanding en na-opstandingverskynings van Jesus geskep is, vroue as getuienisse daarvan aangebied sou word (kyk in hierdie verband veral Gundry 2000:110). ${ }^{29}$ Lukas 24:11 is in hierdie verband interessant. Volgens Lukas 24:11 het die dissipels self die vroue aanvanklik nie geglo nie. 
- Indien die argument aanvaar sou word dat alle vertellinge wat handel oor die opstanding van Jesus skeppinge van die vroeë kerk is, hoekom nie ook die skep van 'n fiktiewe vertelling van ooggetuies wat teenwoordig was toe Jesus opgestaan het nie? In die woorde van Lapide (1983:97): "How easy it would have been for them or their immediate successors to supplement this scandalous hole in the concatenation of events by fanciful embellishments?"30 Op grond van Matteus 28:11-15 blyk dit egter of juis die teendeel waar is: 'n tradisie word geskep om te bevestig dat Jesus juis nie uit die graf opgestaan het nie.

- Die verskeie standpunte dat Jesus deur óf Josef van Arimatea, óf die wat Hom gekruisig het, óf deur Jode begrawe, het as gemene deler 'n graf. Hoekom is daar nie, nadat die dissipels begin verkondig het dat Jesus opgestaan het, eenvoudig gewys op die graf van Jesus waarin sy liggaam (en later ten minste sy beendere) nog teenwoordig was nie? Gundry (2000:114) druk hierdie vraag gepas soos volg uit: "Why did the enemies of Jesus not squelch the message of the resurrection by exposing his remains" (kyk ook Craig 2000a:36, 2000b:56)? Of moet daar met Lüdemann (1994:116) saamgestem word dat dit nie plaasgevind het nie, aangesien die Jode wat Jesus begrawe het, aan 'n "kollektiewe amnesie" gely het? ${ }^{31}$ In hierdie verband maak Wright (2003:579-580, 707) die volgende twee opmerkings wat miskien wel aandag verdien: indien Jesus nie uit die graf opgestaan het nie, hoekom vind ons enersyds geen verwysing na enige verering van sy graf nie, en andersyds, hoekom bestaan daar geen tradisie dat Jesus 'n tweede keer begrawe is nie ${ }^{32}$

- $\quad$ Hoe moet die kontinuïteit (of diskontinuïteit) verstaan word tussen 1 Korintiërs 15:3-8 en die na-opstandingvertellings in die evangelies? Indien die tradisie van Paulus (wat in 1 Kor 15 in debat is met opponente in die gemeente wat nie die liggaamlike opstanding van Jesus aanvaar nie) nie in kontinuïteit sou wees met 'n bestaande en geloofwaardige tradisie nie, sou die argumente van Paulus tog van geen krag gewees het nie. Indien ons die tradisie waarvan Paulus in 1 Korintiërs 15 gebruik maak as histories beskou, kan dieselfde van die tradisies waarvan die evangeliste gebruik gemaak het, gesê word? As verdere argument kan gemeld word die argument van Paulus self in 1 Korintiërs 15:6, wat beweer dat van die vyfhonderd broers aan wie Jesus verskyn het, nog gelewe het toe hy sy eerste brief aan die 
Korintiërs geskryf het. Hierdie persone wat nog geleef het, was tog seker self getuies dat Jesus aan hulle verskyn het.

- $\quad$ Hoe kan dit verklaar word dat die eerste gelowiges die Joodse Sabbat vir die Sondag verruil het? Kan ons hieruit aflei dat hulle werklik geglo het dat op daardie "eerste" Sondag werklik "iets" gebeur het (kyk Blomberg 1998:101; Wright 2003:579-580)?

- $\quad$ Indien Crossan (1995:203) korrek sou wees in sy oortuiging dat die naopstandingverskynings van Jesus eintlik oor gesag, mag en leierskap handel (en dus skeppinge van die vroeë kerk is), moet gevra word hoekom nie een van die tradisies in die Evangelies wat handel oor die na-opstandingverskynings van Jesus spesifiek Jakobus as een van die getuies aandui nie, veral gesien in die lig van die belangrike rol wat Jakobus na Jesus se dood in die gemeente in Jerusalem gespeel het (vgl ook Wright 2003:610).

\section{SLOTOPMERKINGS}

Die opstanding van Jesus uit die dood was 'n gebeure wat die dissipels nie verwag het nie. Geen verstaan of verwagting van die opstanding in hulle tyd het voorsiening gemaak vir so 'n gebeure nie. Nadat Jesus egter aan hulle verskyn het, en hulle die opgestane Here met Jesus van Nasaret kon identifiseer, het hulle verkondig dat Jesus lewe. Interessant is dat die dissipels hulle verkondiging van Jesus se opstanding nie apologeties aanbied nie. Geen vertelling van 'n ooggetuie(s) wat die opstanding gesien het, word geskep nie. Geen vertelling bestaan waarin aangetoon word dat Jesus nog in die graf was nie. Inteendeel. Vertellinge word geskep om te sê dat Jesus se liggaam uit die graf gesteel is (Matt 28:11-15). Teen alle verwagting en rede in word verkondig dat Jesus opgestaan het, en hierdie getuienis(se) word aanvaar en geglo. Wat daarna gebeur is die kerk.

As geskiedenis is die opstanding van Jesus Christus dus nie alleen 'n gebeure in die verlede nie. Dit is verder histories in terme dat dit gesien word as 'n gebeure in die verlede waaroor vertel en geskryf is. Dat dit 'n gebeure is wat duidelik 'n bepaalde effek op die verloop van die geskiedenis gehad het, is ook duidelik. Ten slotte, as van bogenoemde vooronderstellings uitgegaan word, is dit ook 'n gebeure wat histories waarskynlik beskou kan word. Indien daar egter van 'n naturalistiese verstaan van die werklikheid uitgegaan word, bly die opstanding van Jesus Christus 'n onmoontlikheid. 
Ten slotte die volgende opmerking van Wright (2003:712):

The fact that dead people do not ordinarily rise is itself part of early Christian belief, not an objection to it. The early Christians insisted that what had happened to Jesus was precisely something new; was, indeed, the start of a whole new mode of existence, a new creation. The fact that Jesus' resurrection was, and remains, without analogy is not an objection to the early Christian claim. It is part of the claim itself.

(Wright 2003:712)

\section{Endnotas}

${ }^{1}$ Die Heidelbergse Kategismus, Sondag 17 (vraag en antwoord 45), druk dit wat die Christelike kerk oor die nut van die opstanding van Jesus Christus bely, soos volg uit: "Eerstens het Hy deur sy opstanding die dood oorwin, sodat Hy ons die geregtigheid wat Hy deur sy dood verwerf het, deelagtig kon maak. Tweedens word ons nou ook deur sy krag tot 'n nuwe lewe opgewek. Derdens is die opstanding van Christus vir ons 'n betroubare waarborg van ons salige opstanding."

${ }^{2}$ Uit Origines se Contra Celsum (II.5) kan dit afgelei word dat Celsus nie alleen die vroeë Christene se aanspraak dat Jesus opgestaan het as legende afgewys het nie, maar ook al die soortgelyke vertellinge in die Grieks-Romeinse mitologieë as legendaries beskou het. Opstanding was eenvoudig nie ' $\mathrm{n}$ moontlikheid nie (kyk Van Tilborg \& Chatelion Counet 2000:205-208).

${ }^{3}$ In reaksie op argumente van sy tydgenote dat Jesus nie werklik opgestaan het en opgevaar het na die hemel nie, en dat die vertellings oor Jesus se opstanding en hemelvaart binne die raamwerk van die Griekse heldepatroon geïnterpreteer moet word, antwoord Justinus (Apol 1.2, 54; Dialoog met Trifo 69.1-3) soos volg: die Grieks-Romeinse mitologiese vertellinge oor byvoorbeeld Dionusos, Bellerofon, Perseus, Herakles en Asklepios is "kopieë" van OuTestamentiese profesieë soos Genesis 49:11-11, Jesaja 7:14, Jesaja 8:5-6 en Psalm 18:5. Volgens Justinus is die profesieë oor Jesus se lewe en dood dus baie vroeër as die mitologiese vertellinge oor byvoorbeeld Dionusos en Herakles wat sterf, opstaan en na die hemel opvaar. Volgens Justinus is hierdie mitologiese vertellinge oor die Griekse gode wat sterf en opstaan, die "werk van die duiwel" (kyk Van Tilborg \& Chatelion Counet 2000:201204).

${ }^{4}$ Lüdemann (2000a:43) oordeel dat die tradisie oor Josef van Arimatea as tendensieus beskou moet word aangesien hierdie tradisie in die Evangelies ' $n$ bepaalde ontwikkeling toon: In Markus 15:43 word Josef beskryf as 'n vooraanstaande lid van die Joodse Raad wat uitgesien het na die koms van die koninkryk van God; in Matteus 27:57 word hy as 'n volgeling van Jesus beskryf; in Lukas 23:50-51 word hy beskryf as 'n opregte en goeie man; en in Johannes 19:38 word hy beskryf as 'n dissipel van die Here.

${ }^{5}$ Craig (2000b:47) oordeel in hierdie verband dat die uitspraak in Handelinge 13:29 verstaan moet word in terme van die algemene patroon in Handelinge waar die Jode geblameer word wat met Jesus gebeur het. Vergelyk byvoorbeeld Handelinge 2:23 en 36, asook Handelinge 4:10, waarin die Jode gesien word as diegene wat Jesus gekruisig het.

${ }^{6}$ Jung se verstaan van die argetipe kan, simplisties gestel, soos volg uitgedruk word: die argetipe van die self is die belangrikste argetipe, 'n argetipe wat streef na heelheid en 
selfverwerkliking. So word - in die godsdiens - Christus die simbool van die self, en laat dit vir Paulus met 'n onbewustelike Christuskompleks.

${ }^{7}$ Lüdemann se psigologiese interpretasie van die na-opstandingverskynings van Jesus as "visioene" of "gesigte" is natuurlik nie nuut nie. Reeds so vroeg as in die werke van D F Strauss, C H Weisse, F C Baur en C Holsten kom aspekte van 'n psigologiese verstaan van Jesus se na-opstandingverskynings na vore (kyk Lüdemann 1994:54-58). Marxsen (1968:1550), Jenkins (in Harris 1985:337-353) en Carnley (1987:225-227; 1997:29-40; vir 'n goeie opsomming van die standpunt van Carnley, kyk O'Collins 1999:201-209) verstaan die verskynings van Jesus, soos Lüdemann, ook as psigologiese (subjektiewe) visioene. Hick (1993:24-38), op sy beurt weer, verstaan die na-opstandingverskynings van Jesus as óf tipiese "waking versions" of ... "near-death experiences", óf as ervaringe op grond van onopgeloste rousmart (so ook Goulder 2000:86-103).

${ }^{8}$ Die tradisie in die Evangelies dat Josef van Arimatea Jesus begrawe het, is dus ' $n$ skepping van Markus, en nie histories nie (Crossan 1995:172). Dieselfde geld ook vir die vertelling oor die leë graf (Crossan 1995:185).

${ }^{9}$ Crossan se verstaan van die opstanding en na-opstandingvertellings in die Evangelies is nie nuut nie, en kom in wese ooreen met die standpunte van verskeie vroeëre Nuwe-

Testamentici. Bultmann (1953:38-42) se standpunt dat Jesus alleen "in sy woorde" opgestaan het, is welbekend. Lampe (1968:58-59) oordeel ook dat Jesus se opstanding nie noodwendig 'n leë graf impliseer nie, aangesien sy opstanding ook verstaan kan word as dit wat gelowiges hoop. Ook Evans (1970:130) oordeel dat die na-opstandingvertellings so van mekaar verskil, dat dit alleen geloof in 'n moontlike opstanding daarstel. Hy oordeel verder dat nie eers Jesus sy eie dood en opstanding voorspel het nie (Evans 1999:82-97). Jenkins (in Harries 1987:76) oordeel dat Jesus net in die gedagtes van sy dissipels opgestaan het: "the bodily resurrection of Jesus is a conjuring trick with bones." Wedderburn (1999:98) gaan selfs verder, in dat hy oordeel dat die vertellings oor die opstanding van Jesus so onhistories is dat die Christelike geloof alleen maar kan sentreer rondom die lewe wat Jesus geleef en die boodskap wat Hy verkondig het. Crossan se verstaan van die opstanding en na-opstandingverskynings sluit verder lynreg aan by die interpretasie van McFague: "what really happened in Jesus" resurrection was the awareness of his continuing presence and empowerment .... The resurrection is a way of speaking about an awareness that the presence of God in Jesus is a permanent presence in our midst" (McFague 1987:59).

${ }^{10}$ Crossan (1995:204) beskryf Jesus se "verskyning” aan Paulus soos volg: “... Paul's own experience involved trance, that altered state of consciousness well known from all world religions."

${ }^{11}$ Ander Nuwe-Testamentici wat, soos Craig, die historisiteit van die opstanding aanvaar is Beasly-Murray (1947, 1964), Ramsey (1961); Fuller (1968), Ladd (1975), Lapide (1984), O'Collins (1987), Davis (1993) en Wright (Wright \& Borg 1999). Beasly-Murray oordeel dat die opstanding van Jesus as histories aanvaar kan word op grond van die leë graf, die naopstandingverskynings van Jesus, die bestaan van die kerk, die getuienisse van die vroeë Christene, die voorspellings van Jesus wat betref sy dood en opstanding en die kongruensie tussen die opstandingvertellings in die evangelies en die attestasie van die opstanding van Jesus in die res van die Nuwe Testament. Ramsey en Ladd vestig hulle aanvaarding van die historisiteit van die opstanding in die eie aard van die tekste van die Nuwe Testament, te wete dat die Nuwe Testament in die eerste plek as teologie en nie as historie verstaan moet word nie. Fuller, op sy beurt weer, oordeel dat die feitelike bestaan van die Christelike geloof, asook die realiteit van nuwe mens-wees in Christus net verstaan kan word in die lig van die feit dat Jesus opgestaan het en lewe. Lapide grond sy oortuiging wat betref die historisiteit van die opstanding op veral twee argumente: indien die na-opstandingvertellings fiktiewe skeppinge van die vroeë kerk is, sal vroue nie as getuienisse aangebied word nie, en sou die vroeë kerk beslis 'n vertelling wat as inhoud die opstanding van Jesus het, geskep het. O'Collins is van mening dat ten minste vyf sake dui op die historisiteit van Jesus se opstanding: dit toon 'n kontinuïteit met die Joodse verwagting in die tyd van Jesus wat betref die eskatologies algemene opstanding, die koherensie wat betref al die getuienisse in die 
Nuwe Testament wat verwys na die opstanding van Jesus, meervoudige ooggetuienisse van Jesus se opstanding, tekens van die opgestane Heer se handelinge in die antieke en moderne wêreld, en die persoonlike ervaring van die opgestane Here in die lewe van individue. Davis weer, vanuit 'n filosofiese hoek, oordeel dat die feit dat gelowiges sinvol in hierdie wêreld eksisteer vanuit die verwagting van 'n eie opstanding na die dood, alleen kan dui op die historisiteit van die opstanding. Wright, ten slotte, is van mening dat die verskille tussen die onderskeie evangelies wat betref die na-opstandingverskynings nie noodwendig dui op onhistorisiteit nie, maar bloot op verskillende getuienisse oor dieselfde gebeure.

${ }^{12}$ Die problematiek wat hierdie vraag na vore bring, kan goed geïllustreer word met die vertellings in die Nuwe Testament wat as inhoud het die begrafnis van Jesus deur Josef van Arimatea. Bo is aangetoon (kyk Afd 2.2, in besonder voetnoot 8) dat die tradisie wat handel oor die begrafnis van Jesus deur Josef bepaalde ontwikkeling, aanpassing en uitbreiding in die Evangelies ondergaan het. Ook in die Evangelie van Petrus is daar ' $n$ bepaalde ontwikkeling (ander weergawe?) aantoonbaar ten opsigte van die "kerntradisie" in Markus: Josef was 'n vriend van sowel Pilatus en Jesus, en het Pilatus, voor Jesus gekruisig is, gevra om Jesus te mag begrawe. Wat impliseer hierdie verskille? Dat daar 'n historiese "kerntradisie" bestaan het wat aangepas is? Dat die verskille ten opsigte van die verskeie weergawes van die tradisie dui op die onhistorisiteit daarvan? Of, in die woorde van Hoover (2000:132-133) dat "each Gospel author felt free to alter the story to fit his own narrative and to serve his own theological interests?" Dus: is die begrafnis van Jesus deur Josef geskiedenis, of teologie? Of geskiedenis wat teologies aangebied word? Of net teologie, en dus onhistories? Hoover (2000:133) druk hierdie dilemma raak in die volgende opmerking uit: "That is why the question whether the story of Jesus' resurrection is a piece of historical memory, or whether it is a plausible tale created by Mark to fill in the gaps in his historical knowledge and to fit his interpretive interest, is more a judgment call than a matter that can be proved or disproved." Vir Padgett (1997:305) is een saak in hierdie verband duidelik: om eenvoudig te aanvaar (soos bv Lüdemann) dat die tekste van die Nuwe Testament volledig toeganklik vir objektiewe historiese ondersoek is, lei nie alleen tot "bad history" nie, maar ook tot "bad theology".

${ }^{13}$ Padgett (1997:304) maak in hierdie verband die volgende opmerking: "Luedemann insists ... that historical explanation is the only kind of explanation for past events. He rejects any idea that God might actually do anything in history that could be known by people .... In fact, Luedemann's methodology reduces theology to mere social-scientific explanation. Reasons for past events based on the action of God are ruled out a priori. And that is just a piece of Enlightenment bias. Because he refuses to allow the resurrection to be beyond historical explanation, he generates a so-called historical explanation that is patently absurd, based upon pseudo-historical 'depth psychology' as a source for understanding the resurrection." Carnley (1997:34-35) maak egter weer, op sy beurt, in hierdie verband die volgende opmerking: "Luedemann makes out a prima-facie case for a psychogenic explanation of the visions to be taken seriously ... [H]ow might it be possible at this distance and with the fragmentary information at our disposal to rule out this possibility? [I]f one is relying on the evidence of the appearances to provide the historical grounds of faith, then, in strictly historical terms, where is the evidence to come from to rule out the possibility of psychologically induced visions as one explanation of the available evidence?"

${ }^{14}$ Dieselfde verstaan van die werklikheid word ook by Lüdemann gevind, soos duidelik uit die volgende blyk: "[T]he conversion of Paul must in principle be accessible to historical criticism, even if at the present not all the details are known yet. Only through the mediation of an understandable [suiwer histories - EvE] approach to the event of Paul's conversion is it possible to discuss its meaning and its significance ...., A really historical work cannot rest content with a past event which cannot be fully explained by social science" (Lüdemann 1994:59, 80).

${ }^{15}$ Wat hierdie beskouing van historisiteit nog meer problematies maak, is dit wat "selektiewe historisiteit" genoem kan word. Een voorbeeld kan hier genoem word. Volgens Lüdemann (1994:44) is die tradisie(s) in die Evangelies wat handel oor die begrafnis van Jesus deur Josef nie histories nie. Lüdemann (1994:45) is baie stellig in hierdie verband: "nobody knew 
what happened to Jesus' body." Tog maak Lüdemann van presies dieselfde tradisies gebruik om tot die (historiese) slotsom te kom dat Jode (vis-a-vis Crossan se Romeine) Jesus se liggaam van die kruis gehaal en Hom begrawe het. In wese kom Lüdemann se standpunt in hierdie verband op die volgende neer: die tradisies wat in hierdie verband bestaan, is nie histories nie. Tog kan hierdie nie-historiese tradisie gebruik word om 'n historiese uitspraak te maak oor 'n saak waarvoor daar nie 'n tradisie bestaan nie.

${ }^{16}$ Alleen dit wat rasioneel is, kan as histories gesien word. Die na-opstandingsverskynings van Jesus kan daarom alleen psigologies verstaan word. Geloof is belangriker as geskiedenis. Alleen wanneer ervaar word dat Jesus lewe, het dit enige waarde of betekenis vir die gelowige (Strauss 1898:784).

${ }^{17}$ Die wêreld bestaan uit 'n historiese werklikheid en 'n goddelike dimensie. Die opstanding van Jesus val in laasgenoemde sfeer. Die opstanding van Jesus kan dus nie histories ondersoek word nie, dit kan alleen geglo word (Herrmann 1927:84)

${ }^{18}$ Geloof het te make met ' $n$ verhouding tussen God en die individu, en is dus nie gebonde aan die werklikheid nie. Die opstanding van Jesus maak alleen sin op 'n spirituele vlak (Von Harnack 1901:67).

${ }^{19}$ Die Jesus van die geskiedenis is vir ons ' $n$ vreemdeling. Jesus kan alleen geken word los van die geskiedenis en historiese kennis, dus deur die geloof. Die opstanding is 'n psigologiese wonder (Schweitzer 1950:401).

${ }^{20}$ Die kerk is die gevolg van die opstanding van Jesus Christus. Die opstanding kan beskou word as 'n "gebeure" wat historiese belang het (die kerk): "There are events of outstanding historical importance in which practically nothing at all happened, in the original sense of happening. The resurrection of Jesus Christ ... is such an event: one in which the meaning of the "fact" is clearer than the "fact" itself (Dodd 1947:105). Die gebeure self, die opstanding, kan egter nie histories ondersoek word nie.

${ }^{21}$ Die opstanding kan nie as 'n historiese feit beskou word nie, maar moet as 'n bo-historiese of eskatologiese gebeure verstaan word. Die opstanding is ' $n$ "gat" in die geskiedenis, waarvan alleen die rante (van die gat) as histories beskou kan word. Geloof kan egter sekerheid hê oor sekere feite wat objektiewe kennis nie kan hê nie. Die feit dat die opstanding geglo word, beteken dat dit histories is in terme van 'n ewige waarheid (Brunner 1952:328).

${ }^{22}$ Die vroeë Jesusvolgelinge se oortuiging dat Jesus se dood 'n offer vir sonde is, kan alleen verstaan word indien aanvaar word dat hulle oortuig was dat Jesus wel opgestaan het en nou in sy kerk teenwoordig was. Die opstanding van Jesus Christus is die skakel tussen Jesus en die kerk. Die kerk is altyd gemeenskap, en Jesus se lewe, dood en opstanding maak alleen sin as ingesien word dat sy dood en opstanding die kerk as gemeenskap tot stand gebring het. Die gemeenskap van die vroeë gelowiges maak dus die opstanding van Jesus waar (Ritschl 1872:2).

${ }^{23}$ Die opstanding van Jesus Christus kan alleen as openbaring verstaan word. Openbaring is die gawe van geloof, en kennis gegrond op openbaring transendeer kennis van enige historiese gebeure. So verstaan, is die opstanding nie deel van "normale" (historiese) gebeurtenisse nie. In die opstanding van Jesus word alle ander historiese gebeurtenisse saamgevat. Oor die opstanding kan dus nie histories gepraat word nie, die betekenis daarvan kan alleen deur God geopenbaar word. Wat oor die opstanding gesê kan word, kan dus ook nie anders wees as wat die vroeë geloofsgemeenskap daaroor gesê het nie (Barth 1956:58$66,122-128,242-249)$.

${ }^{24}$ Bultmann se eksistensiële verstaan van die kerk se kerugma, asook sy onderskeid tussen Geschichte en Historie is welbekend. Historie (historiese, sosiale en natuurlike feite) maak alleen sin as dit vir die gelowige eksistensieel Geschichte word. Die waarheid van die kruis en opstanding is nie geleë in die feitelike daarvan nie, maar in die eksistensiële verstaan 
daarvan. Die opstanding is die wonder van die ontstaan van die geloof by die vroeë apostels, en dui dus op die betekenis van die kruis (Bultmann 1953:191-205).

${ }^{25}$ Geskiedenis is nie feite nie, maar gebeure. ' $n$ Historiese gebeurtenis is dit wat verstaan en onthou word van 'n feit, en mense daarop laat reageer. 'n Historiese ervaring het met objek en subjek te make, en daarom kan ons nie oor die Jesusgebeure praat sonder die vroeë geloofsgemeenskap se reaksie op die Jesusgebeure nie. So verstaan, vorm die Woord van God, Jesus Christus en die vroeë geloofsgemeenskap 'n triade: dit wat geken word (Jesus Christus), die kenner daarvan (die vroeë geloofsgemeenskap) en die interpretasie van dit wat geken word (Woord van God). Die opstanding kan dus nie as geskiedenis beskou word nie, aangesien dit geïnterpreteerde geskiedenis is. Daar kan alleen van die opstanding gesê word dit wat die vroeë geloofsgemeenskap daaroor gesê het. Die historiese Jesus is daarom die Christus van die geloof. Jesus se opstanding kan dus nie as ' $n$ historiese feit gesien word nie, maar wel as 'n historiese gebeurtenis (Knox 1947:58-101).

${ }^{26}$ Wanneer die opstanding van Jesus aan hierdie beskouing van geskiedenis onderwerp word, is die logiese gevolgtrekking dat dit nie 'n historiese gebeure was nie. Dit lei ook tot verskillende benaderings ten opsigte van die verstaan van die opstanding. Sommige geleerdes oordeel dat 'n historiese ondersoek na die opstanding nie moontlik is nie, aangesien geen historikus daartoe toegang het nie (bv Marxsen). Ander weer, soos Troeltsch, is ook van mening dat 'n historiese ondersoek na die opstanding nie moontlik is nie, aangesien die historikus geen analogiese gebeure uit sy eie ervaring kan gebruik waarteen die opstanding verstaan kan word nie. En ander weer, soos Crossan en Lüdemann (kyk bo), glo dat die opstanding (en na-opstandingverskynings) op een of ander wyse verklaar behoort te word (kyk Wright 2003:15-20).

${ }^{27}$ Daar kan maar net deur die vele publikasies wat die afgelope dekade oor die ondersoek na die historiese Jesus verskyn het, geblaai word om raak te sien dat daar, wat die konstruksie van die historiese Jesus betref, tog 'n sekere konsensus oor 'n aantal sake bestaan. Jesus word byvoorbeeld verstaan as 'n Jood van sy tyd, 'n sosiaal-veragte wat 'n nuwe koninkryk (gemeenskap) deur woorde ('n alternatiewe wysheid) en dade daargestel het waarin gelykheid tussen mense en geslag, onmiddellike toegang tot God, die akkommodering van alle mense (veral die sosiaal-veragtes/onreines), 'n oop tafel en 'n bepaalde verstaan van reinheid 'n pertinente rol gespeel het.

\footnotetext{
${ }^{28}$ Met die konstatering van hierdie "kernel" word natuurlik geensins bedoel dat die tradisies wat hierdie saak oordra nie van mekaar verskil of bepaalde (tendensieuse) ontwikkelinge ondergaan het nie. In die woorde van Wright (1999:122): "[T]his is what eyewitness testimony looks and sounds like ... the surface discrepancies do not mean that nothing happened; rather, they mean that the witnesses have not been in collusion." Die feit dat Jesus soms herken word en soms nie, soms uit die niet verskyn en weer verdwyn en soms deur 'n deur kan beweeg, toon verder hoe raaiselagtig die gebeure van Jesus se opstanding deur die dissipels verstaan is (Wright 1999:122).

${ }^{29}$ In hierdie verband maak Lapide (1984:95-96) die volgende opmerking: "In a purely fictional narrative one would have avoided making woman the crown witnesses of the resurrection since they were considered in rabbinic Judaism as incapable of giving valid testimony .... The circumstance that the same woman wanted to anoint the dead Jesus right after his burial, as Jewish custom demanded, proves that basically none of the disciples nor the women themselves ... expected his resurrection."
}

\footnotetext{
${ }^{30}$ Interessant is dat die Evangelie van Petrus (9:35-11:49), wat deur Crossan (1985) beskou word as 'n dokument komende uit die vroegste strata van die Jesustradisie, wel 'n vertelling bevat waarin die vyande van Jesus (die soldate wat die graf bewaak het, 'n Romeinse hoofman en sekere Joodse familiehoofde) getuienisse is van die opstanding van Jesus.
}

${ }^{31}$ Wat betref die leë graf oordeel Lüdemann $(1994: 44,173)$ dat, indien die graf van Jesus werklik leeg was, die vroeë Christene tog 'n bepaalde verering ten opsigte van Jesus se graf sou getoon het. Gundry (2000:114) is van mening dat juis omdat die graf leeg was, geen 
sodanige verering aangetoon kan word nie. "Tombs as such were not venerated. It was tombs containing remains of the deceased that were venerated" (Gundry 2000:114, voetnoot 10).

${ }^{32}$ Dit was gebruik in die Palestynse Jodedom van die eerste eeu om die beendere van ' $n$ liggaam, nadat dit sorgvuldig begrawe is en geleentheid gegee is om te ontbind, te herbegrawe (Meyers 1971 en Longstaff 1981, in Wright 2003:707).

\section{Literatuurverwysings}

Anderson, N 1973. A lawyer among the theologians. London: Hodder \& Stoughton. Barth, K 1956. Church dogmatics, Vol I. Edinburgh: Clark

Beasly-Murray, G R 1947. Christ is alive. London: Lutterworth.

Beasly-Murray, G R 1964. The resurrection of Jesus Christ. London: Oliphants.

Blomberg, C L 1998. The Jesus of history and the Christ of faith: Harmony or conflict?, in Copan et al 1998:99-116.

Borg, M J 1999. The truth of Easter, in Borg \& Wright 1999:129-142.

Borg, M J \& Wright, N T 1999. The meaning of Jesus: Two visions. New York: HarperCollins.

Brunner, E 1952. The Christian doctrine of creation and redemption, in Dogmatics, Vol II. London: Lutterworth.

Bultmann, R 1953. Kerygma and myth. London: SPCK.

Carnley, P 1987. The structure of resurrection belief. Oxford: Clarendon Press.

Carnley, P 1997. Response by Peter F Carnley, in Davis et al 1997:29-40.

Copan, P H (ed) 1998. Will the real Jesus please stand up? A debate between William Lane Craig and John Dominic Crossan: With repsonses from Robert J Miller, Craig L Blomberg, Marcus Borg and Ben Witherington III. Grand Rapids, MI: Baker Books.

Copan, P H \& Tacelli, R K (eds) 2000. Jesus' resurrection: Fact of figment? A debate between William Lane Craig and Gerd Lüdemann. Illinois, IL: InterVarsity Press.

Craig, W L 1997. John Dominic Crossan on the resurrection of Jesus, in Davis et al 1997:249-271.

Craig, W L 1998. William Lane Craig's rebuttal, in Copan et al 1998:40-44.

Craig, W L 2000a. Opening statements: William Lane Craig, in Copan et al 2000:3139.

Craig, W L 2000b. First rebuttals: William Lane Craig, in Copan et al 2000:46-51.

Craig, W L 2000c. Second rebuttals: William Lane Craig, in Copan et al 2000:56-59.

Craig, W L 2000d. Concluding statements: William Lane Craig, in Copan et al 2000:63-65.

Craig, W L 2000e. Closing responses: William Lane Craig, in Copan et al 2000:162206.

Crossan, J D 1985. Four other Gospels: Shadows on the contours of canon. Minneapolis, MN: Winston.

Crossan, J D 1994: Jesus: A revolutionary biography. New York: HarperCollins. 
Crossan, J D 1995. Who killed Jesus? Exposing the roots of anti-Semitism on the gospel story of the death of Jesus. New York: HarperCollins.

Crossan, J D 2003. Resurrection of Jesus in its Jewish context. NTSSA 37, 29-58.

Davis, S T 1993. Risen indeed: Making sense of the resurrection. London: SPCK.

Davis, S T 2000. The question of miracles, ascension and anti-Semitism, in Copan et al 2000:71-85.

Davis, S T, Kendall, D \& O'Collins, G (eds) 1997. The resurrection: An interdisciplinary symposium on the resurrection of Jesus. Oxford: Oxford University Press.

Dodd, C H 1947. History and gospel. New York: Scribner's sons.

Eddy, P R 1997. Response: Paul Rhodes Eddy, in Davis et al 1997:272-286.

Evans, C F 1970. Resurrection and the New Testament. London: SCM.

Evans, C F 1999. Did Jesus predict his death and resurrection? in Porter et al 1999:82-97.

Fuller, D 1968. Easter faith and history. London: Tyndale.

Goulder, M 2000. The explanatory power of conversion-visions, in Copan et al 2000:86-103.

Gundry, R H 2000. Trimming the debate, in Copan et al 2000:104-123.

Harris, M J 1983. Raised immortal: Resurrection and immortality in the New Testament. London: Marshall, Morgan \& Scott.

Harris, M J 1985. Easter in Durham. London: Paternoster.

Harries, J 1987. Christ is risen. London: Mowbray.

Herrmann, W 1927. Systematic theology. London: Marshall, Morgan \& Scott.

Hick, J 1993. The metaphor of God incarnate. London: SCM.

Hooke, S H 1967. The resurrection of Christ as history and experience. London:

Darton, Longman \& Todd.

Hoover, R W. 2000. A contests between orthodoxy and veracity, in Copan et al 2000:124-147.

Knox, J 1947. The man Jesus Christ. London: Marshall, Morgan \& Scott.

Ladd, G E 1975. I believe the resurrection. London: Hodder \& Stoughton.

Lampe, G W H \& MacKinnon, D 1966. The resurrection: A dialogue. London:

Mowbray.

Lapide, P 1984. The resurrection of Jesus: A Jewish perspective. London: SPCK.

Lüdemann, G 1994. The resurrection of Jesus: History, experience, theology. Minneapolis,MN: Fortress Press.

Lüdemann, G 2000a. Opening statements: Gerd Lüdemann, in Copan et al 2000:4045.

Lüdemann, G 2000b. First rebuttals: Gerd Lüdemann, in Copan et al 2000:52-55.

Lüdemann, G 2000c. Second rebuttals: Gerd Lüdemann, in Copan et al 2000:60-62.

Lüdemann, G 2000d. Concluding statements: Gerd Lüdemann, in Copan et al 2000:66-70.

Lüdemann, G 2000e. Closing responses: Gerd Lüdemann, in Copan et al 2000:149161. 
Marxsen, W 1968. The resurrection of Jesus as a historical and theological problem, in Moule, C F D (ed), The significance of the message of the resurrection for the faith in Jesus Christ. London: SCM.

McFaque, S 1987. Models of God: Theology for an ecological, nuclear age. London: SCM.

Niebuhr, R R 1957. Resurrection and historical reason: A study of theological method. New York: Charles Scribner's Sons.

O'Collins, G 1997. The resurrection: The state of the questions, in Davis et al 1997:528.

O'Collins, G 1999. The risen Jersus, in Porter et al 1999:195-217.

Padgett, A G 1997. Advice for the religious historians: On the myth of the purely historical Jesus, in Davis et al 1997:287-307.

Porter, S E 1999. Resurrection, the Greeks and the New Testament, in Porter et al 1999:52-81.

Porter, S E, Hayes, M A \& Tombs, D (reds) 1999. Resurrection. Sheffield: Sheffield Academic Press (Journal for the study of the New Testament Supplement Series 186.)

Ramsey, A M 1961. The resurrection of Christ: A study of the event and its meaning for the Christian faith. London: Collins.

Riley, G J 1995. Resurrection reconsidered: Thomas and John in controversy. Minneapolis, MN: Fortress Press.

Ritschl, A 1872. A critical history of the Christian doctrine of justification and reconciliation. London: Collins.

Schweitzer, A 1950. The quest for the historical Jesus. London: Black.

Strauss, D F 1975. Life of Jesus. London: SCM.

Tolston, J 1992. Pilgrim in ruins: A life of Walker Percy. New York: Simon \& Schuster.

Van Eck, E 1995. Galilee and Jerusalem in Mark's story of Jesus: A narratological and social-scientific reading. Pretoria: Kital. (HTS Suppl 7.)

Van Eck, E 2004. Die opstanding in die Jodedom, die Grieks-Romeinse wêreld en die Nuwe Testament. HTS 60(1\&2), 533-552.

Van Tilborg, S \& Chatelion Counet, P 2000. Jesus' appearances and disappearances in Luke 24. Leiden: Brill.

Von Harnack, A 1901. What is Christianity? London: Williams \& Norgale.

Wedderburn, A J M 1999. Beyond resurrection. London: SCM.

Witherington III, B 1998. Resurrection redux, in Copan et al 1998:129-145.

Wright, N T \& Borg, M 1999. The meaning of Jesus: Two visions. London: SPCK.

Wright, N T 2003. Christian origins and the people of God, Vol 3. The resurrection of the Son of God. Minneapolis, MN: Fortress Press. 